\title{
The Impact of Listening Strategy on Listening Comprehension
}

\author{
Yan Zhang \\ Foreign Languages Teaching School of Shandong University of Finance and Economics, Jinan, Shandong, China \\ Email: zhyan1997@sina.com
}

\begin{abstract}
Successful FL learners are characterized by knowing how to use language learning strategies effectively. This article reports a study of the effect of strategy training on listening comprehension. In the study, 56 intermediate foreign language learners at Shandong Economic College were either participants in a strategies-based instructional treatment or were comparison students receiving the regular listening course. Data were obtained and analyzed through the performance of a set of three listening tasks on a pre-post basis by both groups. The subsample of twelve students also provided verbal report data to show their cognitive insights into strategy use and the instruction itself. It was found that the increased use of listening strategy contributed positively to listening comprehension, which led to the implication that formal strategy training should have a role in the foreign language listening classroom.
\end{abstract}

Index Terms - impact, strategy training, listening comprehension

\section{INTRODUCTION}

Listening has rightly assumed a central role in language learning, but it is still an area where students feel most frustrated and helpless. In China's English teaching, listening has been emphasized since the mid-1980s, but this skill remains poor for many learners even after they have had six to ten years of experience in learning English. One major reason lies in the teaching and learning methodology. It is true that teaching learners how to solve a listening task by using an array of strategies will lead to better comprehension. But for many teachers, teaching listening is the easiest of all English courses. All they have to do is to play the tape, let the students listen and do the comprehension exercises, play the tape again and check up. There is no doubt that teaching practice in this aspect has generally failed to catch up with the progress of EFL theory. The objective of classroom teaching is to help students develop listening strategies and skills instead of providing random practice. In light of many new discoveries and advances in understanding the nature of listening and the strategies and skills involved, this article considers the impact of strategy training on listening comprehension. It briefly reviews literature related to this issue, and then focuses on a study conducted at Shandong Economic College, in the study, 56 intermediate foreign language learners at Shandong Economic College were either participants in a strategies-based instructional treatment or were comparison students receiving the regular listening course. The data analysis looked for links between an increase in the use of certain strategies included in the strategy list as the result of strategy training and an improvement in rated performance. The aim of the strategy training was to help the learners become more aware of the strategies they could use to learn more effectively, to monitor and to evaluate their listening process.

\section{LitERATURE REVIEW}

The area of learning strategy research has grown dramatically over the last twenty years. "The skills underlying listening have become more clearly defined" and "strategies contributing to effective listening are now better understood" (Rost, 2001, p.12). "A strategy-based approach teaches learners how to listen effectively by instructing them in the use of strategies" (Mendeldohn, 1995, p.134). Mendelsohn (1995) argues that a strategy-based approach towards teaching listening benefits learners in a number of ways. First of all, it helps learners listen more effectively. Research has shown that in general, good listeners use a variety of metacognitive, cognitive, social and affective strategies and strategy instruction does help improve listening comprehension (Cohen, 1990). The first major development was the publication of The Good Language Learner: a Report (Nairnan et al., 1975), which reported that successful language learners tended to use certain strategies. The underlying premise was that if one could identify the strategies adopted by good language learners and then teach poor language learners to use such strategies, these less effective learners would become more able to handle language learning demands. However, there have been some criticisms of this matter. Bialystok argued that "the human ability to incorporate forms of thought or ideas that are radically different from present experience seems to be severely limited" (Bialystok, 1985, p.259). Some people asserted that learners need not be taught L2 compensation strategies because they already had them in their LI. More importantly, those studies which were completed in the field of foreign language strategy training were not especially encouraging in their results. So it is necessary to conduct more empirical studies to evaluate the effect of strategy 
training on language learners.

This study set out to examine the impact that formal strategy training might have on learners in university-level foreign language classrooms, with a particular focus on listening, because this area had received limited attention in research literature on strategy training.

\section{RESEARCH DESIGN}

\section{A. Sample}

The sample consisted of 56 second-year non-English major students at Shandong Economic College. They were from two intact classes. One class of 30 comprised the experimental group and received strategies-based listening instruction. The other class of 26 served as a comparison group. Twelve students out of the total 56 were selected on a volunteer basis to provide additional data in the form of verbal report protocols regarding their strategy use. These students represented three different levels of listening ability in their respective classes (4 high-level, 4 mid-level and another 4 low-level).

\section{B. Instrumentation and Data Collection Procedures \\ TREATMENT}

All subjects were administered a pre-treatment questionnaire to measure their knowledge of listening strategies, their use of these strategies and their perception of the value of the strategies. Then the teacher and the experimental students together worked out a list of strategies useful for the students' listening task performance based on O'Malley and Chamot's model. The list mainly included:

Metacognitive strategies

Self-monitoring: Checking and correcting one's comprehension while the listening task is taking place.

Directed attention: Deciding in advance to attend to the listening task and ignore irrelevant distracters.

Selective attention: Deciding in advance to attend to specific aspects or situational details that will cue the retention of listening material.

Self-evaluation: Checking the outcomes of the performance.

Self-reinforcement: Arranging rewards for oneself when the task has been accomplished successfully.

Cognitive strategies

Elaboration: Relating new information to other concepts in memory.

Inferencing: Using available information to guess meanings of new items, predict outcomes, or fill in missing information.

Note-taking: Writing down the main idea, important points, outline, or summary of information presented in the listening task.

Transfer: Using previously acquired linguistic and/or conceptual knowledge to facilitate a listening task.

Social / affective strategies

Cooperation: Working with one or more peers to obtain feedback, pool information, or model a listening activity.

Both the experimental and the comparison groups followed the routine syllabus. The students in the experimental group also received listening strategy training throughout the 15 -week class. The strategies were incorporated into regular classroom activities rather than presented separately.

\section{INSTRUMENT}

Listening task battery

A Listening Task Battery was designed and made up of a series of three listening tasks (two sets with 6 individual tasks). All subjects from the experimental and comparison groups were asked to complete the similar three tasks on a pre-and post-test basis to determine whether there were gains in listening ability for the experimental students over the 15 -week training. The listening materials used in this study were almost at the same level of difficulty. And three different types of listening tasks (a story, a news report, and a scientific story) were expected to elicit a range of listening strategies.

Verbal report protocols

The post-test data collection also included an extra feature for the subsample of the 12 students from both the experimental and comparison groups. These subjects were first asked to describe what was going on in their minds before, during and after the listening process, and what strategies they used, and finally why they used certain specific strategies.

\section{DATA ANALYSIS PROCEDURES}

The different listening tasks were rated according to a set of five-point, multi-trait scales. Data obtained from the preand post-test listening tasks were used to determine students' improvement in listening proficiency. The effect of increased frequency of use of a given strategy was calculated by correlating the gains in listening performance in general.

As indicated above, the verbal report data were analyzed separately from the listening task data, and aimed at students' insights into strategy use and feedback of the instruction. This verbal report served as a qualitative means for determining whether the training was reliable and valid, and the results are reported in 4.2 below. 


\section{FINDINGS}

\section{A. Research Question 1: The Effect of Strategy Training on Listening Proficiency}

In response to our first research question, regarding the effect of strategy training on listening proficiency, the results of pre- and post- test means showed that the experimental group outperformed the comparison group on all the three tasks (see Table 4. 1). And the correlation data suggested a significant relationship between the increased use of strategies and task performance (Table 4.2).

TABLE 4.1:

OVERALL LISTENING PERFORMANCE BY TASK PRE- AND POST-TEST MEANS

$\begin{array}{lccc} & \text { OVERALL LISTENING PERFORMANCE BY TASK PRE- AND POST-TEST MEANS } \\ \text { Pre- and post- test means } & \text { Task } 1 & \text { Task } 2 & \text { Task } 3 \\ & \text { A story } & \text { A news report } & \text { A science story } \\ \begin{array}{l}\text { Experimental group } \\ (\mathrm{N}=30)\end{array} & 3.95 / 4.34 & 3.60 / 4.05 & 3.22 / 3.73 \\ & & & 3.18 / 3.20 \\ \begin{array}{l}\text { Comparison } \\ \text { group }\end{array} & 3.86 / 3.91 & 3.63 / 3.70 & \\ (\mathrm{~N}=26) & & & \end{array}$

TABLE 4.2:

GAIN IN TASK PERFORMANCE IN GENERAL CORRELATED WITH GAIN IN REPORTED FREQUENCY OF STRATEGY USE BY EXPERIMENTAL STUDENTS

$\begin{array}{llll}\text { Listening strategies } & \text { pre-test } & \text { post-test } & \text { performance } \\ \text { Self-monitoring } & 2.61 & 4.17 & .52 \\ \text { Directed attention } & 3.36 & 4.38 & .48 \\ \text { Selective attention } & 3.24 & 4.25 & .47 \\ \text { Self-evaluation } & 2.75 & 3.97 & .40 \\ \text { Inferencing } & 3.23 & 4.23 & .53 \\ \text { Elaboration } & 3.50 & 4.45 & .53 \\ \text { Note-taking } & 3.02 & 4.56 & .58\end{array}$

\section{B. Research Question 2: Students' Use of the Instructed Strategies}

Verbal report collected from the subsample of students was intended to measure the effect of strategy training from a cognitive perspective. The verbal report protocols yielded two types of data-insights about students' strategy use as well as their reactions towards such training program, as presented below.

Experimental group

Pre-test

"Tried to get every word as well as the main idea"

"Paid attention to the specific things, like the time, the place, the name of the person."

"Cannot predict what is going to happen."

"Never thought of using specific strategies."

Post-test

"Learned about my language learning"

"How bad my listening skills are."

"Able to understand from context the words that I didn't know."

"I need to relax myself a little more in order to listen more attentively."

"Writing it down helps."

"I will summarize the story after listening."

"I'm trying to listen attentively."

"I want more training so as to make full use of the strategies."

"Discussing with my classmates is helpful." "I benefit from the training."

Comparison group

Pre-test

"I thought if I could remember every word I could understand everything."

"It's easier to listen to something you're familiar with."

"I translate what I hear into Chinese and then think in Chinese."

Post-test

"When I realized that I was not listening to the tape, became very upset, and what was left become meaningless."

"When I met a new word, I became very nervous. I kept thinking hard for the meaning of it and then missed the following sentences."

"I have difficulty understanding all these strategies. I have never heard them before."

"1 don't know when and how to use these strategies on the list, but I want to learn them."

\section{DISCUSSION}

With regard to the question of whether strategy training makes a difference in listening performance, the finding 
seemed to be positive: the experimental group outperformed; the comparison group on all the three tasks. Students tended to use listening strategies more frequently due to the treatment with a direct result in their gains in the task performance. It was quite understandable that note-taking, among all the strategies listed in Table 4.2, got the highest correlation coefficient, because it was the easiest one to perform. It seemed that self-monitoring, inferencing and elaboration are the other important strategies that would enhance listening ability. For the comparison group, the preand post- test mea-difference was too small to be counted, but could be then take-as a natural improvement of the course study. The verbal report showed that strategy training did help students with their listening comprehension. We found that students, having been instructed, seemed to have more valuable insights about the performance of language tasks, and about their language learning. Some students had realized that by relaxing more, they understood more and the task became easier to perform. A student even had the insight that thanks to the strategy training, he had learned how to listen more effectively.

There were indications from the comparison group that the students could use some strategies without training, but only unconsciously and at a very basic level, as one student claimed that he found listening to a familiar topic was much easier, which would mean that he had used elaboration and inferencing strategies. However this does not suggest that the instruction is unnecessary, for several students from the comparison group shared the same experience that they were not familiar with the strategies in the training list and expressed willingness to be trained in order to improve their listening ability.

Finally, one big problem was found that the students were poor at using metacognitive strategies. For example, when interrupted, they had difficulty in redirecting their attention immediately to the listening task. Besides, they tended to use more bottom- up processing (such as repetition, translation, etc) than the top-down processing strategies (such as inferencing, elaboration, etc), as they tried to understand the whole thing by catching each individual word that they had heard. These findings call for the regulation of the teachers' attention when they give formal strategies-based instruction in the classroom.

\section{Pedagogical Implications}

This study was undertaken to see whether strategy training should have a role in the foreign language listening classroom. It would seem that the results speak in favor of such a role. So what could and should be done is, above all, concerned with two things: reflection and flexibility. "Reflection represents the learner developing some degree of self-awareness in learning, and shows how a given learner may appreciate his or her strengths and weaknesses. Flexibility arising from metacognitive strategy use organizes and gives purpose to the way cognitive and social-affective strategies are used, and increase the likelihood of appropriateness of strategy choice" (Skehan, 1998, p.265). That is to say, strategy training is intended to raise the students' awareness of metacognitive strategies, through which the learner is more able to select strategies appropriate to a particular problem, rather than engage in the activity for its own sake. To make it simple, students should not be only taught what to learn, but also how to learn.

Every teacher should realize the importance and necessity of listening strategy training, and find some effective ways to carry out strategy training in listening teaching. A teaching approach involves providing helpful support and strategy training to help students succeed in listening comprehension and preparing them for effective functioning in real-life situations. But the Goal of any ESL/EFL language programme should be learner independence (Krashen, 1981). Classroom instructions in listening serve to raise student awareness of listening strategies/skills, assess their listening ability and problems, and build up their confidence. Classroom instructions usually address only common problems, leaving individual differences untouched. It is therefore important for students, preferably under teacher's guidance, to assess their own weaknesses, make a plan to develop relevant strategies and skills and stick to it. Students also need to be exposed to a variety of authentic input outside class. Teacher's guidance in the initial habit-forming stage can be crucial in providing motivation, encouragement and a bit pressure to keep it going.

\section{CONCLUSION}

This study provided suggestions that it would appear beneficial to engage learners in discussions of listening strategies, and practice those strategies in class. If instructors systematically introduce and reinforce strategies, the students might listen more effectively. A listening teacher's role is far from the mechanical operation of tape-recorders. The teacher has to be conscious of listening skills and strategies and assess student needs to formulate teaching objectives; to choose appropriate input materials and design graded pre-, while-, and post- listening tasks if the textbook proves inadequate; and above all, the teacher needs to help students develop learning strategy, which will benefit them. All those efforts will be adequately rewarded with greater student confidence, autonomy and fulfillment.

There are still some limitations in the study, such as the lack of direct link between each task performance and the reported specific strategy use on a pre-post test basis, which should be considered in further studies.

\section{REFERENCES}

[1] Bialystok, E. (1985). The compatibility of teaching and learning strategies. Applied Linguistics 6: 155-262.

[2] Brown, G. (1986). Investigating Listening Comprehension in Context. Applied Linguistics 7/3: 284-302. 
[3] Buck, G. (1995). How to Become a Good Listening Teacher. In Mendelsohn, D. \& Rubin, J. (eds.) A Guide for the Teaching of Second Language Listening. San Diego: Dominie Press, Inc. 113-131.

[4] Cohen, Andrew D. (1990). Language Learning: Insights for Learners, the Teacher, and Researcher. Boston: Heinle \& Heinle.

[5] Cohen, Andrew D. (1998). Strategies in Learning and Using a Second Language. New York: Addison Wesley Longman Limited.

[6] Ellis, Rod. (1994). The Study of Second Language Acquisition. Oxford: Oxford University Press.

[7] Freeman, D. L. \& M. H. Long, (1991). An Introduction to Second Language Acquisition Research. Longman Group UK Limited.

[8] Krashen, S. (1981). Second Language Acquisition and Second Language Learning. Oxford: Pergamon Press.

[9] Mendelsohn, D. (1994). Learning to Listen: A Strategy-based Approach for the Second Language Learner. San Diego: Dominie Press.

[10] Mendelsohn, D. (1995). Applying Learning Strategies in the Second/Foreign Language Listening Comprehension Lesson. In Mendelsohn, D. \& Rubin J. (eds.) A Guide for the Teaching of Second Language Listening. San Diego: Dominie Press, Inc.

[11] Nairnan, N. et al. (1975). The Good Language Learner: a Report. Ontario: Ontario Institute for Studies in Education.

[12] O’ Malley, J. \& A. Chamot, (1990). Learning Strategies in Second Language Acquisition. Cambridge: Cambridge University Press.

[13] Oxford, R. (1990). Language Learning Strategies: What Every Teacher Should Know. Rowley, Mass: Newbury House.

[14] Rost, M. (2001). Listening, in Carter, R. \& D. Nunan (eds.). The Cambridge Guide to Teaching English to Speakers of Other Languages. Cambridge: Cambridge University Press.

[15] Skehan, P. (1998). A Cognitive Approach to Language Learning. Oxford: Oxford University Press.

[16] Underwood, M. (1989). Teaching Listening. London: Longman.

Yan Zhang was born in Qingdao, China in 1974. She received her M.A. degree in literature from Shandong University, China in 1996.

She is currently a lecturer in the School of Foreign Languages, Shandong University of Finance and Economics, Jinan, China. Her research interests include linguistics and American literature.

Ms. Zhang is a member of the Chinese Association of Foreign Language Teachers. 